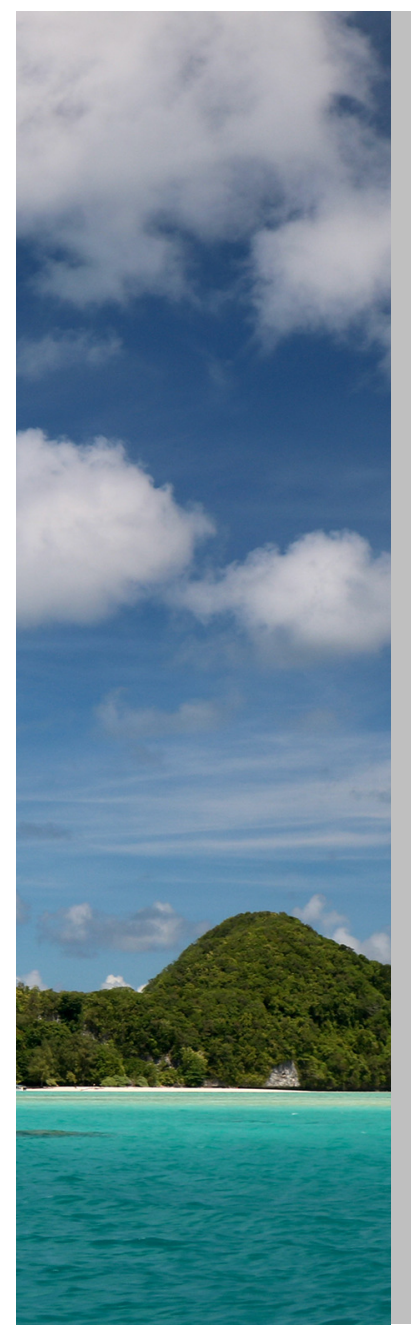

\title{
COVID-ERA POLICIES AND ECONOMIC RECOVERY PLANS: ARE GOVERNMENTS BUILDING BACK BETTER FOR PROTECTED AND CONSERVED AREAS?
}

\author{
Rachel Golden Kroner ${ }^{* 1}$, Edward B. Barbier ${ }^{2}$, Olivier Chassot ${ }^{3}$, Sunita \\ Chaudhary ${ }^{4}$, Lorenzo Cordova Jr 5 , Annabelle Cruz-Trinidad 6 , Tracey \\ Cumming ${ }^{6}$, Jennifer Howard7, Charlotte Karibuhoye Said ${ }^{8}$, Zoltan Kun 9 , \\ Angelique Ogena ${ }^{5}$, Florence Palla ${ }^{10}$, Rodrigo Samayoa Valiente ${ }^{11}$, Sebastian \\ Troëng ${ }^{12}$, Allan Valverde ${ }^{3}$, Ramitha Wijethunga ${ }^{13}$ and Michael Wong ${ }^{14}$
}

\author{
*Corresponding author: rgolden@conservation.org \\ ${ }^{1}$ Moore Center for Science, Conservation International, 2011 Crystal Drive, Arlington, VA, \\ 22202, USA \\ ${ }^{2}$ Department of Economics, Colorado State University, Fort Collins, CO, 80523, USA \\ ${ }^{3}$ University for International Cooperation, Avenida 15, Calle 35, Barrio Escalante, San José \\ 10101, Costa Rica \\ ${ }^{4}$ International Centre for Integrated Mountain Development (ICIMOD), Lalitpur 3226, \\ Kathmandu, Nepal \\ ${ }^{5}$ Biodiversity Finance Initiative, United Nations Development Programme, 1554 \\ Mandaluyong City, Philippines \\ ${ }^{6}$ Biodiversity Finance Initiative, United Nations Development Programme, 304 East 45th \\ Street, New York, NY 10017
}

Author affiliations continue on page 147

\section{ABSTRACT}

The COVID-19 pandemic is having a major impact on conservation policies and practice at multiple scales, including protected and conserved areas (PCAs). There is a need to understand the implications for PCAs of recent actions, enacted or promoted in the wake of COVID-19. To fill this knowledge gap, we reviewed economic stimulus packages and other government policies that were implemented or advanced between January and October 2020. We identified positive examples of support for PCAs in economic recovery packages (in 17 countries) and instances where commitments made before 2020 to scale up environmental protections were advanced (in 22 countries), but also rollbacks of protection measures (64 cases in 22 countries). On balance, post-COVID economic stimulus packages and policies to date have undermined more than supported environmental protections, including for PCAs; rollbacks may have long-term consequences where they authorise damaging infrastructure or undermine Indigenous rights. We suggest priority actions for a green economic recovery that include putting PCAs at the centre of such efforts, helping ensure the long-term prosperity of people and our planet.

Key words: economic recovery, conservation finance, COVID-19, regulations, rollbacks, IPLC

\section{INTRODUCTION}

Destruction of the natural environment is directly linked to outbreaks of pandemics. The zoonotic origin of COVID-19 demonstrates the complex links between the health of people and the health of nature, and underscores the importance of avoiding habitat loss and fragmentation to prevent future pandemics (Gibb et al., 2020; Shah et al., 2018). When well-designed and wellmanaged, PCAs not only protect intact ecosystems, they also offer economic and health benefits. Protected areas and areas conserved by Indigenous Peoples and Local Communities (IPLC); or Indigenous and Community Conserved Areas can play a significant role in maintaining intact ecosystems (Andam et al., 2008; BenYishay et al., 2017; Geldmann et al., 2013; Terraube \& Fernández-Llamazares, 2020). Recent analyses demonstrate a 5-to-1 return on environmental investments in protected areas (Waldron et al., 2020) based on the numerous ecosystem services they can provide, including climate mitigation and resilience 
building. When well-designed, and effectively and equitably managed, PCAs can assist vulnerable communities and support sustainable livelihoods (Naidoo et al., 2019) through food security and quality (Basurto, 2018; Cabral et al., 2020; Kawarazuka \& Béné, 2011). Cost-effective investments in PCAs to avoid ecosystem degradation, along with efforts to curb the illegal wildlife trade, have the potential to reduce the risk of future pandemics (ICIMOD, 2020). Billions spent in prevention means societies can avoid spending trillions on coping with the health and economic impacts of environmental degradation and associated pandemics (Dobson et al., 2020). Less straightforward to quantify but no less important are the existence, cultural and spiritual values provided by PCAs.

The COVID-19 pandemic has had a devastating impact on public health and the global economy. All nations are now focusing on economic recovery efforts to support health and livelihoods and to provide immediate relief. At the same time, in many countries, the public funds available for conservation have been cut. Yet the climate and nature crises are becoming ever more serious. Half of the world's GDP is moderately or highly dependent on nature and its services, but current funding for environmental protection is insufficient; the 'biodiversity financing gap' is estimated at around US\$ 700 billion (WEF, 2020; Deutz et al., 2020).

Notwithstanding this, the current period of economic recovery provides an unprecedented opportunity for nations to make rapid shifts towards green and sustainable investments, including through investments in nature protection. The protection of natural capital, including ecosystem resilience and regeneration, protects biodiversity and helps mitigate, and adapt to, climate change; it can also be an economic multiplier (Hepburn et al., 2020). Investments in nature-based solutions, including protecting and restoring PCAs, can foster long-term health, ecosystem services and biodiversity benefits, as well as promote job creation (Hockings et al., 2020). Although achieving equitable management of PCAs globally requires additional attention (Zafra-Calvo et al., 2019), well-managed protected areas can advance social development agendas, including fair employment, sustainable food production and safe drinking water access (Stolton et al., 2015).

The pandemic - and responses to it - also threaten some conservation efforts. Many national economies are in danger of collapse (Wren, 2020; McKibbin \& Fernando, 2020). Reduced government budgets and weakened enforcement have led to increased illegal deforestation (Brancalion et al., 2020), and more poaching. The loss of funding previously provided by tourism may further weaken PCA effectiveness (Corlett et al., 2020). At a time when the public is understandably preoccupied and unable to participate in decision-making processes, some governments may undermine, weaken or re-interpret environmental regulations and their implementation, in order to realise short-term economic gains. These risks compound historical underfunding of PCAs (Waldron et al., 2020). Therefore, economic recovery efforts should not only involve short-term expansion and support for PCAs (including management capacity (Gill et al., 2017)), but also institute safeguards to ensure long-term sustainability and effective performance.

There is a crucial need to understand how governments' decisions, plans and actions have affected PCAs during the COVID-19 pandemic, including through economic recovery packages, budgets, regulatory changes and other policies. This article takes stock of government actions that have been enacted or proposed between January and October 2020 and have affected or may affect PCAs including economic recovery plans and other policies. It considers the benefits and drawbacks for PCAs, and suggests lessons that can inform near and longer-term economic recovery efforts and ensure sustainable conservation financing for a post-COVID world. Information presented is necessarily illustrative, rather than comprehensive, and does not include information about distribution equity, as policies and economic recovery plans are evolving rapidly and most such plans have yet to be fully implemented.

\section{METHODS}

This essay draws from the principles which Hockings et al. (2020) believe should guide the first two phases of the PCA response to the pandemic, specifically: (1) Rescue (including maintain existing laws) and (2) Recovery (including adopt a sustainable and equitable recovery). We ask the following framing questions:

- Do countries pledge funding that directly supports, or has the potential to support, PCAs within COVID19 economic recovery packages? Which ones? How?

- Have countries scaled up policies or laws in support of PCAs, or increased PCA budgets, during the COVID-19 pandemic? Which ones? How?

- Have countries postponed, weakened or terminated environmental laws and regulations, or reduced PCA budgets during the COVID-19 pandemic? Which ones?

To address these questions, we synthesised information from the best available data, documents, literature and 
websites that described policies and national economic recovery plans which affect or may affect PCAs. We organise results in four sections: (1) Examples of economic recovery packages with likely direct support for PCAs; (2) Examples of economic recovery with the potential to support PCAs; (3) examples of advancements or continuations of pre-pandemic commitments during 2020 that support PCAs; and (4) Rollbacks to environmental protections (defined here as weakening or terminating environmental laws or regulations, and reducing budgets). The geographical scope of the review is global, aiming to include as wide and diverse representation of geographies as possible. The study includes policies and economic recovery plans that were proposed or advanced between January and October 2020.

In our review of economic recovery packages ${ }^{1,2,3}$, associated reports, websites (e.g. global and regional hubs and trackers4,5,6), news and other sources (see Supplementary Online Material - Methods for more details), we noted cases in which one or more of the following supportive provisions were adopted or proposed:

- Expansion, upgrade or improved connectivity of PCAs (we took an inclusive approach to ensure a variety of area-based conservation efforts were recognised);

- Increased funding to improve management;

- Support for the tenure, access and human rights of IPLCs, for co-management schemes, and for provisions to ensure equitable distribution of benefits;

- Investments in ecological restoration that include a focus on PCAs;

- Investments in monitoring zoonoses in and around PCAs, which may boost local employment and assist in pandemic prevention;

- Support for long-term sustainability of PCAs, including:

- Investments in community resilience to compensate for loss of tourism revenue (e.g. direct support, debt restructuring);

- Support for PCA-related employment (e.g. for improved visitor access, nature-based education and invasive species eradication);

- Other investments that support PCAs and their conservation.

After extracting relevant examples from economic recovery packages, we also determined whether these elements were likely to (1) directly, or (2) have the

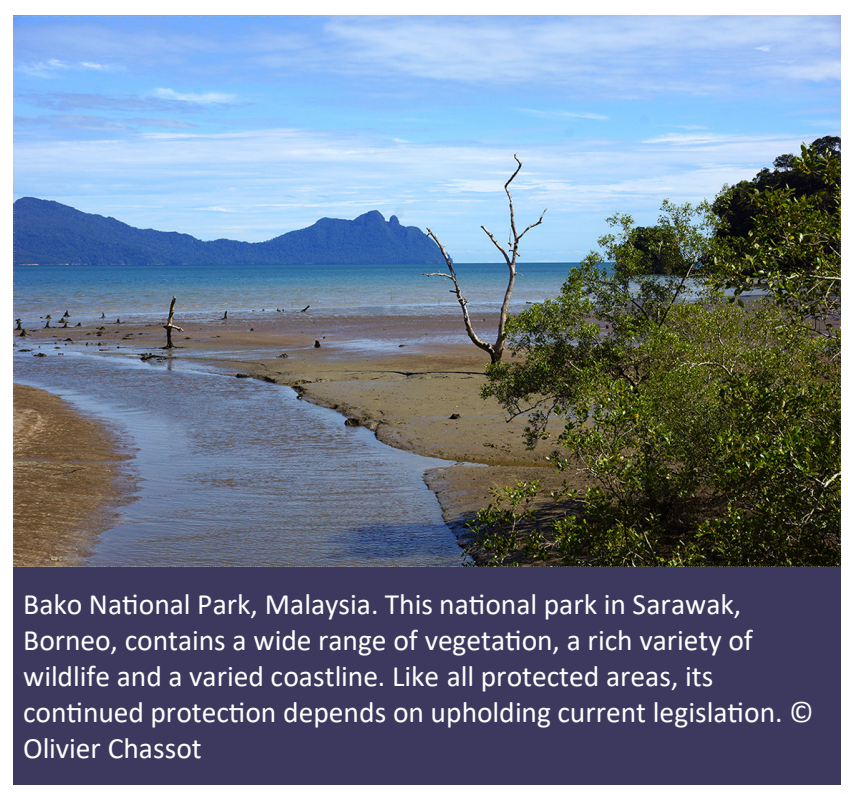

potential to directly, support PCAs. Since information was not always available on whether funds directly target PCAs, we used available details in recovery plans to categorise each example (e.g. as either direct or potential support), and only included examples in the direct category if details in recovery plans were sufficiently clear. We note that some examples provided describe a plan or broader package that involves not only support for PCAs but also other initiatives. When available, we provide information relevant for PCA support, but note that the level of detail available to segment this information is limited for most countries to date.

We also identified examples of advancements or continuations of pre-pandemic commitments that support PCAs, by reviewing relevant news and reports, from which we extracted illustrative examples. To identify rollbacks to PCA laws, regulations and budgets, we drew information from online trackers and reports 7,8 and supplemented results with online searches. We recognise that our review of budget cuts is incomplete; other publications (Waithaka et al., 2021) provide more comprehensive information on this point. If needed, we reached out to regional experts (e.g. IUCN WCPA members, local NGO staff) to supplement and validate information, especially if documents were not available online. We provide more detailed explanation of research strategies in the Supplementary Online Materials - Methods.

A few caveats and limitations apply to this review. Some countries may have enacted both rollbacks and planned positive stimulus efforts for PCAs; we note both separately, but a measurement of the relative or net 
impacts of these opposing actions is outside the scope of this analysis. As we focus on countries where national economic recovery plans and policies have advanced, and for which information is available, this review is necessarily illustrative, rather than comprehensive, and does not indicate global trends. To focus the review, we do not cover an in-depth survey of enforcement or implementation of existing or new laws. To date, most economic recovery packages represent plans that are not yet detailed or implemented; assessment of the impacts of proposed or recently advanced economic recovery plans and other policies will require future research. Finally, the availability of information relies on transparency and press freedoms (if reported through news outlets), which is limited in some cases. 9

\section{RESULTS}

Economic recovery efforts in response to the pandemic have been significant: trillions of dollars have been committed in a few short months, with near-term focus on relief and livelihoods. ${ }^{10,11}$ G2O nations have pledged $\sim$ US\$ 12.1 trillion, including stimulus funding of at least US\$ 3.7 trillion which could directly affect nature in one of three ways. It could lead to rollbacks of environmental protections; herald a return to business as usual; or initiate a transition to a greener economic model $^{1}$. At best, only 10 per cent of the US\$ 12-13 trillion dedicated to COVID-19 stimulus can be considered additional 'green stimulus' (Barbier et al., 2020), and only a modest fraction of currently planned global stimulus will put the world on track to achieve the Paris Climate Agreement goals (Andrijevic et al., 2020). Most earmarked green funding in recovery packages supports renewable energy, green infrastructure and transport; less support has been pledged to support activities related to land use. ${ }^{12}$

A recent analysis finds that recovery efforts in 16 of 20 major economies invested in or focused more on activities that undermine environmental protections rather than support them. Examples of rollbacks to PCAs are highlighted below. A review of economic stimulus efforts in 11 Asia-Pacific region countries demonstrates similar results (Carnell et al., 2020). Limited reference to PCAs or biodiversity was found in recovery plans in Africa; for instance, Senegal is focusing on restoring and accelerating the pre-COVID growth trajectory by emphasising endogenous development and a strong private sector ${ }^{13}$, although the country is moving ahead with the designation of three marine protected areas. In Latin America and the Caribbean, some governments are considering limiting their spending in the environmental sector ${ }^{14,15}$, and resorting to international loans, while others have promoted local PCA-based tourism.16,17 Globally, while economic recovery plans from some countries support environmental protections more than they undermine them, most of them are heavily skewed towards unsustainable development (e.g. de-regulation, subsidies to polluting industries and easing permitting processes). On balance, the largest economies of the world are failing to 'build back better' in terms of support for green initiatives and nature protection in economic recovery packages.

We highlight here examples of stimulus plans that likely directly support PCAs (from 9 countries) or have the potential to directly support them (from 10 countries), pledging at least US\$ 31.918 billion (and furthering part of the efforts pledged in the US\$ 249 billion Next Generation EU package). In addition, we provide examples from 22 countries that are acting on and/or continuing to advance previous commitments to scale up and increase support for PCAs despite the pandemic (see Supplementary Online Materials - Results). All values are converted to US $\$$ for consistency, with original currency values where available to provide contextually appropriate information for each country; bolded numbers below indicate those used for summary statistics.

\section{Examples of economic recovery packages likely to directly support PCAs}

Eight countries and the EU earmarked support to expand and connect PCAs, including state and community governance systems; to manage PCAs (e.g. restoration, tourism); and to establish new PCA institutions.

- EU: The 'Next Generation EU' recovery package proposes to commit US $\$ 249$ billion of its stimulus funds (30 per cent of the total US\$ 830 billion) towards green initiatives, including US\$ $\mathbf{1 1 . 7 4}$ billion ( $€ 10$ billion) for "natural capital and circular economy"18 (other funds would support decarbonisation, green infrastructure and renewable energy). It also stipulates 'do no harm' environmental safeguards. The package supports the implementation of the EU Biodiversity Strategy for 2030, which promotes the protection of at least 30 per cent of Europe's lands and seas in effectively managed and well-connected protected areas ${ }^{19}$, and supports sustainable agriculture, reversing the decline of pollinators and reducing the use of harmful pesticides..$^{20,21}$

- Finland: US\$ $\mathbf{1 5 . 3 8}$ million ( $€ 13.1$ million) has been pledged for state-run rehabilitation of nature sites and the development of nature tourism, as well 
as US\$ 62.23 million ( $€ 53$ million) for projects involving green areas, water services and forest conservation. US\$23.74 million ( $€ 20$ million) of this is appropriated for voluntary forest conservation and US\$ 15.2 million ( $€ 13.1$ million) for the rehabilitation of local recreation areas. ${ }^{22}$

- Iceland: US\$ $\mathbf{4 . 7 4}$ million (ISK 650 million) is committed for tourism infrastructure in protected areas. 23

- Japan: A programme has been announced to promote tourism and 'workation' (telework and vacation) in national parks (level of funding unclear). ${ }^{24}$

- Kenya: Support pledged for conservation in PCAs through promotion of tourism, including employment of 5,500 community scouts under the Kenya Wildlife Service (US\$ 9.2 million, or 1 billion Ksh) and 160 community conservancies (US\$ 9.2 million, or 1 billion Ksh). 25

- New Zealand: US\$ 850 million ( $\$ 1.245$ billion NZD) has been pledged to create 11,000 jobs in support of the following four initiatives: regional environmental projects to restore wetlands and riverbanks (US $\$ 287.80$ million or $\$ 433$ million NZD, 4,0oo jobs over five years); pest eradication and management (US\$ 209.37 million or $\$ 315$ million NZD, 600 jobs annually); a 'Jobs for Nature programme' to manage public lands, involving predator control, wetland restoration, regenerative planting, recreation and visitor improvements (US\$ 132.93 million or $\$ 200$ million NZD); and public and private land management to restore indigenous biodiversity and habitat, revegetation of conservation land and riparian planting (US\$ 102.36

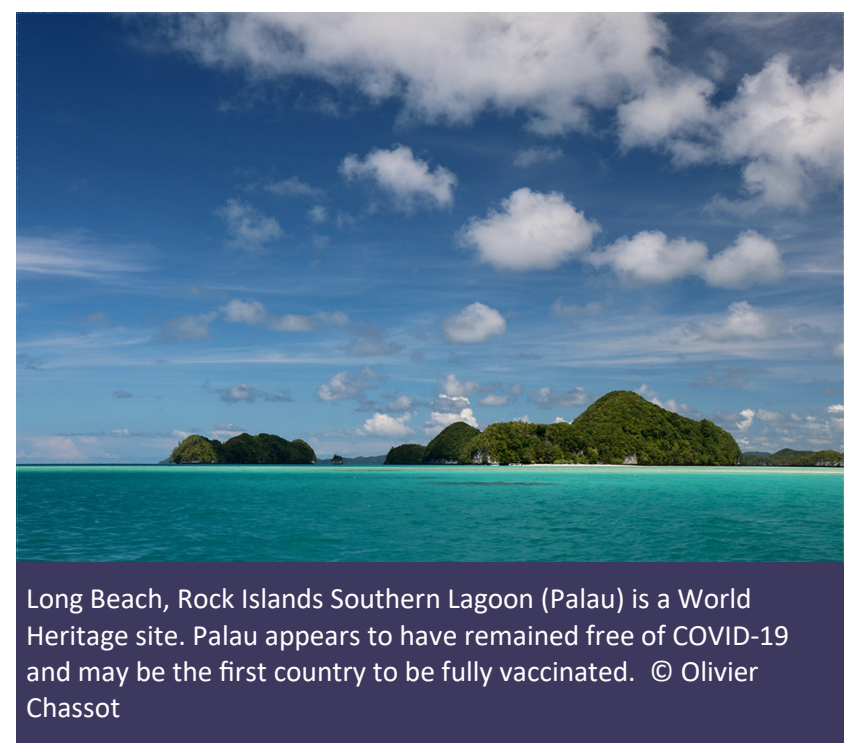

million, \$154 million NZD, 1,800 jobs). ${ }^{26,27,28,29,30}$

- Pakistan: Green Stimulus Initiative includes plans to expand protected areas, the addition of 15 national parks covering over $7,300 \mathrm{~km} 2$ (supported with Rs4 billion or US\$ 24 million); launch of Pakistan's first National Parks Service; and $\sim 5,000$ new jobs. ${ }^{31}$

- Sweden: The Swedish government has proposed a 33 per cent increase in the 2021 budget for environment and nature protection. ${ }^{32}$

- United Kingdom: Local Nature Recovery Strategies initiative earmarks US\$ $\mathbf{1 . 2 9 7}$ million ( $£ 1$ million) to connect protected areas, restore 500,000 hectares of wildlife habitat outside protected areas, and support urban green and blue infrastructure (e.g. floodplains, wetlands, rivers and forests). 33

\section{Examples of economic recovery with the potential to support PCAs}

Ten countries earmarked support to invest in initiatives related to nature-based solutions, green infrastructure, international conservation, sustainable tourism and job creation in restoration.

- China: The Green Development Fund proposes to provide green investments worth US\$ $\mathbf{1 2 . 6 6}$ billion ( 88.5 billion yuan) in the Yangtze River economic belt, support environmental protection, ecological restoration, pollution control, clean energy and green transportation. 34

- Ethiopia: US\$ 3.6 million (133.02 ETB) is pledged for nature-based solutions to tackle climate change and foster a green recovery, including support for ecological restoration and community management. 35

- Germany: US\$ 821.86 million ( $€ 700$ million) is earmarked for conservation and sustainable management of forests. Responding to COVID, the German Government's International Climate Initiative (IKI) dedicated US\$ 58 million (€68 million) in support of 29 projects in 25 countries to build economic, social and ecological resilience, and prevent future pandemics. ${ }^{36}$

- India: Approximately US\$ 817 million (Rs 6,000 crores) has been committed for jobs (including those available to tribal communities) in forest management, wildlife protection, afforestation and plantation work. $37,38,39$

- Ireland: US\$ $\mathbf{1 7 . 6 1}$ million ( $€ 15$ million) has been added to the existing peatland rehabilitation fund of US\$ 5.87 million ( $€ 5$ million) to restore 33,000 hectares of peatlands, thereby maintaining or 
creating jobs. 40,41

- Nepal: A province-level green recovery initiative has been initiated, providing jobs to hundreds of people staying at quarantine centres to plant trees; in four months, more than 7,000 trees were planted in and around public spaces. 42

- Singapore: US\$ $\mathbf{3 . 8 7}$ billion ( $\mathrm{SG} \$ 5$ billion) for Coastal and Flood Protection Fund has been pledged for protection against rising sea levels with both hard infrastructure and nature-based solutions. 43

- Sri Lanka: The Ministry of Tourism and Sri Lanka Tourism Development Authority introduced a sustainable destination development certification programme to promote sustainable tourism, and reduced the tourism development levy by 0.5 per cent while reinvesting that amount in biodiversityfriendly projects (pers. comm. Secretary of the Ministry of Tourism, Sri Lanka).

- Sweden: US\$ 16 million (SEK 150 million) is earmarked for nature conservation and forest management to provide jobs, increase recreation opportunities and reduce the spread of pests. 44

\section{- United Kingdom:}

- The Green Jobs Challenge Fund plans to invest US\$ 51.83 million ( $£ 40$ million), supporting up to 5,000 jobs, while "planting trees, restoring habitats, clearing waterways, and creating green space for people and wildlife.” 45,46

- The pilot Natural Capital and Ecosystem Assessment is being launched with US\$ 6.48 million ( $£ 5$ million) committed to "improve the baseline understanding of habitats and species abundance" for evidence-informed conservation decisions. 47

\section{Examples of advancements or continuations of pre-pandemic commitments during 2020 that support PCAs}

At least 22 countries have advanced pre-pandemic commitments that support PCAs, including new legal frameworks and institutions for PCAs (e.g. Namibia, Uruguay); PCA establishment, upgrading and/or expansion (e.g. Belize, El Salvador, India, Saudi Arabia, Senegal, Seychelles, Turkey); commitments to expand and/or strengthen PCAs (e.g. Canada, China, Peru, Romania, Russia); PCA management (Argentina, Nepal, the United States); and international PCA investments (e.g. Germany). Other ongoing activities include support for diverse forms of PCA governance (e.g. Canada, Cameroon) and research in PCAs to minimise risks of infectious zoonotic diseases (e.g. Guinea-
Bissau). A complete list with details is provided in Supplementary Online Material - Results.

\section{Rollbacks to environmental protections}

During the pandemic to date, the governments of at least 22 countries rolled back or weakened environmental protections for PCAs or reduced PCA budgets. We identified 64 examples of rollbacks that were advanced, enacted or proposed between January and October 2020, which directly affect PCAs or the rights of IPLCs; or which involve legal changes that generally weaken environmental regulations and will likely affect PCAs (e.g. changes to the National Environmental Protection Act in the United States). Some were explicitly tied to economic recovery efforts, while others were not. Supplementary Online Material Results Table 2 and online trackers give more information. ${ }^{8,48}$ Most often, rollbacks that directly affect PCAs authorise new or expanded industrial and/or extractive activities, including: large-scale infrastructure (roads, airports, pipelines, hydropower plants, coal plants, housing developments, telecommunications infrastructure, space infrastructure) and extractive activities (coal, oil and gas development, other mining, logging, industrial fishing). Brazil, India and the United States are emerging hotspots of COVID-era rollbacks. However, the government of Cameroon reversed its plans to log the Ebo Forest after protests.49,50 There have also been other rollbacks to environmental protections that indirectly affect PCAs by weakening climate regulations, and species and air quality protection. For example, all G20 members (except for the EU) have included bailouts or tax relief to support fossil-fuel intensive industries (airlines, coal, natural gas, biofuels) in their economic stimulus packages, and/or amended environmental regulations and procedures, including weakening public comment processes, environmental impact assessments and reviews, permit approvals and enforcement. ${ }^{1}$ We provide illustrative examples below, especially those rollbacks that are likely to directly affect PCAs, and provide the full list in the Supplementary Online Materials - Results; additional information on these other rollbacks can be found through online trackers.51,52,53

\section{Brazil}

- Proposal to allow mining and oil and gas extraction within Indigenous reserves 54 ;

- Proposal to allow land regularisation within Indigenous reserves, which would allow "squatters on public land to more easily receive deeds to their properties" and accelerate deforestation 55 ; 
- Revivals of plans to build new large highways (BR163 and BR-319)56,57;

- Decision to revoke 'permanent protection zones' which safeguard mangroves and other key ecosystems. ${ }^{5}$

Cameroon (rollback reversal):

- Approval of a logging concession in the Ebo Forest cancelled; the proposal would have affected more than 68,000 hectares of primary forest.59,60

\section{Canada}

- Proposal to eliminate protective status for 175 provincial parks in Alberta (closure and/or removal from Parks system and reversion to public land), following amendment that removed the requirement for public consultation in these types of decisions. ${ }^{61}$

\section{Cook Islands}

- Allowance of exploration of minerals, with plans to develop commercial mining within five years, was justified by decision-makers based on country's need to reduce dependence on tourism, following COVIDera travel restrictions. ${ }^{62}$

\section{Ecuador}

- Increasing road construction into Yasuní National Park, bringing oil development closer to the territory of Indigenous people in voluntary isolation ${ }^{63}$;

- Layoffs of 398 staff of the Ministry of Environment and Water, including 30 staff from the National System of Protected Areas. ${ }^{64}$

\section{El Salvador}

- Reduction of budget for Ministry of Environment and Natural Resources, which manages protected areas, by US\$ 1.4 million. 65

\section{Greece}

- Approval of oil and gas exploration in protected areas. 66

\section{India}

- At least 31 proposals ${ }^{67}$ to open up National Parks and Sanctuaries for infrastructure, extraction and development projects, including coal mining in Dehing Patkai Elephant Reserve. ${ }^{68}$ Proposed change of rules to ease environmental clearance processes, for many projects like dams, mines, airports and highways (e.g. by removing public hearing requirements). 69

\section{Kenya}

- Plans to construct a road7o, eco-lodge, high-end restaurant and amphitheatre in Nairobi National Park. ${ }^{71}$

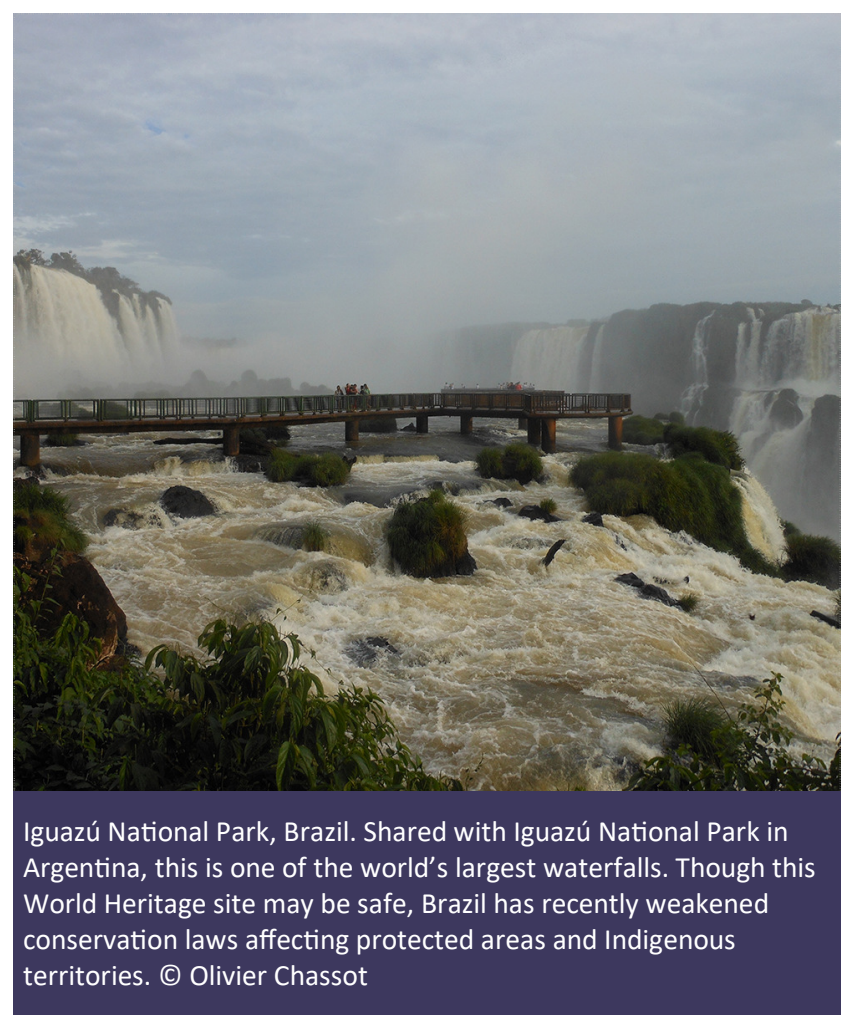

\section{Malaysia}

- Proposed reduction by 97 per cent of the Kuala Langat Forest Reserve, which supports traditional livelihoods of Orang Asli peoples. ${ }^{72}$

\section{Mexico}

- Budget cuts announced by the President to reduce the operational budget of almost all government entities by 75 per cent, including for the National Natural Protected Areas Commission (CONANP).73,74

\section{Poland}

- Adjustment of the definition of the type of wood that can be burned in powerplants, including "deadwood and dying trees" and allowance of sanitary logging; may lead to forest harvest in protected Natura 2000 sites. $75,76,77$

\section{Russia}

- New law permits deforestation in specially protected natural areas to build or update transport infrastructure, and suspends requirements for environmental impact evaluations. ${ }^{78}$

\section{United Kingdom}

- Approval of housing development near proposed national park and Area of Outstanding Natural Beauty 79 and approval of spaceport in area protected under the Conservation of Habitats and Species Regulations $^{80,81}$ 


\section{United States}

- Revision to management plans to allow increased development within the previously downsized Bears Ears and Grand-Staircase Escalante ${ }^{82}$ National Monuments;

- Advancement to plans to explore and drill for oil and gas in the Arctic National Wildlife Refuge: offering of oil and gas leases ${ }^{83}$; approval of seismic testing to measure oil and gas potential84; authorisation of incidental harming or killing of polar bears during oil and gas exploration ${ }^{85}$; auction of oil and gas leases ${ }^{86}$;

- Allowance of hunting of bear cubs, baiting bears and killing swimming caribou from motorboats within national preserves in Alaska ${ }^{87}$;

- Authorisation of commercial fishing in the Northeast Canyons and Seamounts National Monument ${ }^{88}$;

- Weakening of environmental reviews under the National Environmental Policy ${ }^{89}$.

\section{DISCUSSION \\ Implications of near-term commitments that support or undermine PCAs}

Our review illustrates that recent policies and economic recovery plans around the world have a variety of implications for PCAs. There are some positive signs: some countries have adopted elements of a sustainable and equitable recovery, including a few that have earmarked direct support for PCAs and related activities (e.g. restoration, tourism). The EU's recovery plan stands out ${ }^{1}$, with the largest amount of green investments, although the EU Green Deal could offshore environmental damage elsewhere (Fuchs et al., 2020). Also, some countries have continued to advance on environmental protection commitments and make new commitments despite the pandemic.

On the other hand, we report many examples of rollbacks to environmental protections, including those affecting PCAs. Environmental laws, regulations and initiatives have been weakened or abandoned and budgets cut in some countries. Rollbacks to protected areas are not new, and have been increasing over the last two decades, including protected area downgrading, downsizing and degazettement (PADDD) events (Golden Kroner et al., 2019). Most countries do not hold PADDD decisions to the same rigorous processes of public consultation and technical justification that are required for creating PCAs (Pack et al., 2016). Moreover, many recent rollbacks have been allowed at a time when the public cannot properly participate in decision-making processes.
Rollbacks to PCAs can undermine global efforts to conserve biodiversity, address climate change and protect ecologically important areas (Forrest et al., 2015; Golden Kroner et al., 2019). Moreover, they could exacerbate the conditions that favour a future pandemic by increasing ecosystem loss and fragmentation, and bringing wildlife in closer contact with human populations due to increased development (Gibb et al., 2020; Shah et al., 2018). Furthermore, rollbacks could set a precedent and offer moral license to other countries (Golden Kroner et al., 2019).

As some countries have engaged in both rollbacks and positive actions, it is vital to monitor and report on both progression and regression in PCAs, not only net change. The Post-2020 Global Biodiversity Framework provides an opportunity to encourage tracking of both positive and negative changes (Bacon et al., 2019; Maxwell et al., 2020; Qin et al., 2019), ensuring transparency and accountability. Whether rollbacks are enacted during a crisis or not, decisions that undermine environmental protections represent short-term thinking at the expense of long-term planetary and societal prosperity.

\section{Implications of recent policy changes and economic stimulus efforts for IPLCs}

Approximately 50 per cent of the world's lands are traditionally owned, managed, used or occupied by Indigenous peoples and local communities, which overlaps with significant biodiversity and intact forests (Fa et al., 2020; Schuster et al., 2019; Wily 2011). Lands stewarded by Indigenous communities have lower deforestation and carbon emissions (e.g. in Brazil) (BenYishay et al., 2017; Walker et al., 2020), and are home to equivalent biodiversity as state protected areas in some countries (Schuster et al., 2019). However, the voices of IPLCs have historically been marginalised in national and global biodiversity conservation policy contexts (FPP et al., 2020). During the COVID-19 pandemic, rollbacks to lands and waters stewarded by IPLCs have been proposed that could expand or fasttrack extractive activities (e.g. mining and oil and gas) in Australia, Brazil and the Philippines.90,91 IPLCs in Brazil face the simultaneous challenges of COVID-19, fires, and proposals to allow mining on their territories that would affect 222 culturally unique Indigenous groups, $863,000 \mathrm{~km}^{2}$ of Amazon forests, which provide more than US\$ 5 billion annually in ecosystem services (Siqueira-Gay et al., 2020; Villén-Pérez et al., 2020). In the Philippines, after languishing for more than two decades due to opposition from local Indigenous peoples and civil society groups, the Tampakan gold and 
copper mine was granted an extension to operate for 12 years ${ }^{2}$ and subsequently received approval from the National Commission on Indigenous Peoples; its mine tailings will potentially impact the Liguasan Marsh, a key biodiversity wetland. COVID-related closures are also disproportionately affecting marginalised communities, including some IPLC groups, by restricting access to food and sources of income (Bennett et al., 2020). There is an urgent need for the PCA community to follow the lead of IPLCs, to empower them and collaborate with them, given their critical role as environmental stewards (FPP et al., 2020).

\section{Building forward beyond COVID-19}

Drawing from our results, existing best practices and literature93, and noting relevant recovery recommendations from other organisations (see Supplemental Table 2), we recommend the following priority actions for economic recovery from the COVID19 crisis, in addition to supporting current and future PCAs and fostering enabling conditions for long-term conservation. Our results demonstrating widespread rollbacks to budgets and restrictions for PCAs, including IPLC rights, provide fresh urgency to these recommendations. Any actions taken should follow the principles of good governance (participation, inclusion, transparency, and evidence- and rights-based decisionmaking) and equitable distribution of benefits (including women, youth and IPLCs). Details of specific approaches should be tailored to local circumstances.

\section{Near-term priorities for a sustainable recovery}

Do no harm and avoid rollbacks that undermine PCAs. Ensure that recovery efforts, including taxes, subsidies and other incentives, do not undermine nature protections, encourage fossil fuel emissions or exacerbate land-use change. Although PCA budgets are under pressure, efforts should be made to maintain budgets (e.g. as in the Philippines), keep staff on board, and prioritise the most important management actions (Hockings et al., 2020; Lindsey et al., 2020). Transparent decision-making and continued tracking of economic recovery efforts and commitments (including rollbacks) will be necessary as additional economic recovery plans emerge.

Create a supportive, enabling environment for PCAs. Recovery efforts should recognise the role of PCAs in rebuilding economies and societies, and maintain and enhance existing laws, regulations, funding, enforcement and other support for PCAs. Enabling conditions should include 'green strings', where bailouts are tied to strengthened regulations for nature protection (e.g. as in the EU's package, where recovery loans are conditional on pledges to align with sustainable investment and climate risk goals ${ }^{1}$ ). Further, recovery efforts can provide jobs in PCAs (e.g. for ecosystem restoration, patrols, management action) and support the tourism industry while favouring conservation.

\section{Recognise, support and protect IPLC territories and rights.}

Since many IPLCs face increasing rollbacks and are vulnerable to COVID-19, they require emergency relief (e.g. as earmarked for Indigenous peoples in Canada94). Their territorial and resource rights, as well as traditional knowledge systems need to be recognised, and they must be able to participate meaningfully in decision-making processes.

\section{Address the immediate PCA funding shortfall.}

'Green recovery' approaches should include tangible benefits for biodiversity and PCAs. The World Economic Forum estimates that it will take only US $\$ 140$ billion to protect 30 per cent of the planet 95 , a fraction of the more than US\$ 12 trillion that has been pledged for COVID relief. In addition to the current pledges, as listed in the results here, PCA-directed funding (e.g. from government budgets, official development assistance, philanthropy) should support staff to manage, monitor and enforce protections and restoration efforts, and can provide maximum conservation impact by targeting areas with high biodiversity and irrecoverable carbon (Goldstein et al., 2020; Hockings et al., 2020; Lindsey et al., 2020). Adequate funding should be administered within well-designed and well-managed institutional systems; the IUCN Green List for Protected Areas criteria $^{96}$ (good governance, sound design and planning, effective management, conservation outcomes) provides a standard to achieve, or at least aspire to.

\section{Longer-term needs for PCAs: sustainable financing, effective policies and enforcement, and transformative change}

Support for PCAs in the medium- to longer term requires sustainable financing for conservation, diversification and innovation. This could include 'rainy day' funds to bridge downturns in visitation financed from trust funds or other sources; private investments that compensate community conservancies that are paid back as tourism recovers (e.g. in Maasai Mara, Kenya97); and other domestic efforts that can generate revenue for conservation in the absence of external donations (Barbier \& Burgess, 2020). Innovative financing mechanisms, including debt-for-nature swaps 98 and green and blue bonds, could support conservation and help to solve the sovereign debt crisis simultaneously. 
There are many additional finance mechanisms that can be used to support PCAs, suited to different environments and contexts. These include carbon credits, biodiversity offsets, payments for ecosystem services, nature linked endowments, natural infrastructure investments, conservation trust funds, taxing carbon to pay for natural climate solutions, carbon markets, incorporation of nature insurance and reinsurance schemes ${ }^{99}$, and certification schemes (Barbier et al., 2020; Barbier \& Burgess, 2020; Deutz et al., 2020; Lindsey et al., 2020; Claes et al., 2020; World Bank Group 2020).

Transformative changes in the mid- to longer term will be required to ensure the durability and performance of PCAs. These may include financial models that support PCAs rather than cause harm, embracing diverse PCA governance systems including: guaranteeing meaningful leadership and participation of IPLCs; incorporating natural capital into national budgets; recognising the rights of nature ${ }^{100}$, and accounting for economic prosperity through approaches that go beyond GDP towards more holistic measures (e.g. Bhutan's Gross National Happiness ${ }^{101}$ ). The removal of perverse incentives, including subsidies which undermine nature protections, and institution of safeguards (e.g. in government policy and the finance sector) would promote longer-term sustainability of PCAs. Sufficient funds to monitor adherence to and enforcement of safeguards will also be required. More detailed recommendations for resilient funding for PCAs are provided in Cumming et al. (2021). The conservation community may also consider using 'conservation basic incomes' to compensate communities on the front lines of nature stewardship (Fletcher \& Büscher, 2020). Overall, there is a need to deepen the connections between people and the rest of nature, including through experiences in PCAs, and build long-term, broad-based support for conservation efforts, along with a global reduction in overconsumption and waste - especially by the global North.

\section{CONCLUSION}

Despite evidence and arguments for more significant investment in PCAs to safeguard against future zoonoses outbreaks and pandemics, to date funding for COVID-19 economic stimulus packages more often undermines than supports conservation efforts ${ }^{1}$, increasing the risk of "subsidising the emergence of future pandemics".102 Short-term thinking and the increasing pace of rollbacks will weaken environmental protections and put nature, including ourselves, at greater risk. Instead of leaving this legacy for future generations, governments have the unique opportunity to scale up nature protection, including direct support for PCAs. This offers cost-effective solutions for climate, biodiversity, sustainable development goals and pandemic prevention, especially in rural areas where most poverty is concentrated. The global community must support conservation efforts and human, animal and environmental health now and in the longer term as humanity faces the prospect of climate change and future pandemics.

Recent commitments signal increased momentum for nature protection; for instance, dozens of countries have signed the Leaders' Pledge for Nature ${ }^{103}$, which calls for protection of at least 30 per cent of land and sea by 2030. However, more countries need to support PCAs. More funds are needed for PCA implementation, monitoring, evaluation and learning. And continued political support - following the principles of equity, diversity, inclusion and justice - is necessary to ensure successful conservation efforts in the post-COVID era and beyond. The upcoming negotiations of the Post2020 Global Biodiversity Framework of the UN Convention on Biological Diversity provide a near-term opportunity for ambitious action for PCAs. The UNFCCC COP in 2021 should be the occasion to promote natural climate solutions and how these might relate to a global carbon market under Article 6.

Post-COVID recovery is a once in a generation opportunity to deliver proper financing to PCAs, and ensure society can reap the biodiversity conservation, climate and socioeconomic benefits they provide. There is no time to waste.

\section{ENDNOTES}

See Supplementary Online Material - Endnotes

\section{SUPPLEMENTARY ONLINE MATERIAL}
1. Supplementary Methods
2. Supplementary Results
3. Endnotes

\section{DISCLAIMER}

The views and interpretations in this paper are those of the authors and they are not necessarily attributable to their organizations.

\section{ABOUT THE AUTHORS}

Rachel Golden Kroner, $\mathrm{PhD}$, is the Environmental Governance Fellow at Conservation International, and co-chairs the IUCN COVID and Protected Areas task force. Orcid: oooo-0003-1844-3398 
Edward B. Barbier, $\mathrm{PhD}$, is a University Distinguished Professor in the Department of Economics, Colorado State University. Orcid:0ooo0o02-5354-3995

Olivier Chassot, $\mathrm{PhD}$, is Deputy Vice-Chair and Central American Lead of the Connectivity Conservation Specialists Group of the WCPA. Orcid:0000-0003-3061-2203

Sunita Chaudhary, PhD, is the Ecosystem Services Specialist at International Centre for Integrated Mountain Development (ICIMOD)

Lorenzo Cordova Jr. is the Lead Consultant for UNDP-BIOFIN in the Philippines.

Annabelle Cruz-Trinidad (Abbie) is a Senior Technical Advisor to UNDP-BIOFIN.

Tracey Cumming is Technical Advisor to UNDPBIOFIN, and a member of the CBD Panel of Experts on Resource Mobilisation

Jennifer Howard, $\mathrm{PhD}$, is Senior Director of the Blue Carbon Program at Conservation International.

Charlotte Karibuhoye Said, PhD, is the Director of the West Africa program for the MAVA Foundation.

Zoltan Kun works with various nature conservation NGOs such as FZS, PFPI, and Wild Europe. Orcid:00oo $-0002-4688-8936$

Angelique Ogena is a development communicator for UNDP-BIOFIN and the Department of Environment and Natural Resources.

Florence Palla, PhD, is Deputy Regional Vice Chair, WCPA West and Central Africa.

Rodrigo Samayoa Valiente is a Sustainable Business Development professional focused on Environmental Sustainability and Corporate Governance.

Sebastian Troëng, PhD. is Executive Vice President of Conservation Partnerships at Conservation International.

Allan Valverde is the Dean of the Faculty of Environment and Development at the University for International Cooperation, Costa Rica.

Ramitha Wijethunga is the National Project Coordinator of UNDP-BIOFIN and other biodiversity management initiatives in Sri Lanka.
Michael Wong is Chair for the North America Region of the World Commission on Protected Areas of the IUCN.

\section{REFERENCES}

Andam, K.S., Ferraro, P.J., Pfaff, A., Sanchez-Azofeifa, G.A. and Robalino, J.A. (2008). Measuring the effectiveness of protected area networks in reducing deforestation. Proceedings of the National Academy of Sciences, 105(42): 16089-16094. https://doi.org/10.1073/pnas.0800437105

Andrijevic, M., Schleussner, C.-F., Gidden, M.J., McCollum, D.L. and Rogelj, J. (2020). COVID-19 recovery funds dwarf clean energy investment needs. Science, 370(6514): 298-300. https://doi.org/10.1126/science.abc9697

Bacon, E., Gannon, P., Stephen, S., Seyoum-Edjigu, E., Schmidt, M., Lang, B., et al. (2019). Aichi Biodiversity Target 11 in the like-minded megadiverse countries. Journal for Nature Conservation, 51: 125723. https://doi.org/10.1016/ j.jnc.2019.125723

Barbier, E.B. and Burgess, J.C. (2020). Sustainability and development after COVID-19. World Development, 135: 105082. https://doi.org/10.1016/j.worlddev.2020.105082

Barbier, E.B., Lozano, R., Rodríguez, C.M. and Troëng, S. (2020). Adopt a carbon tax to protect tropical forests. Nature, 578 (7794): 213-216. https://doi.org/10.1038/d41586-020-00324w

Basurto, X. (2018). Linking MPA effectiveness to the future of local rural fishing societies. ICES Journal of Marine Science, 75(3): 1193-1194. https://doi.org/10.1093/icesjms/fsx075

Bennett, N.J., Finkbeiner, E.M., Ban, N.C., Belhabib, D., Jupiter, S.D., Kittinger, J.N., Mangubhai, S., Scholtens, J., Gill, D. and Christie, P. (2020). The COVID-19 Pandemic, Small-Scale Fisheries and Coastal Fishing Communities. Coastal Management, 48(4): 336-347. https:// doi.org/10.1080/08920753.2020.1766937

BenYishay, A., Heuser, S., Runfola, D. and Trichler, R. (2017). Indigenous land rights and deforestation: Evidence from the Brazilian Amazon. Journal of Environmental Economics and Management, 86: 29-47. https://doi.org/10.1016/ j.jeem.2017.07.008

Brancalion, P.H.S., Broadbent, E.N., de-Miguel, S., Cardil, A., Rosa, M.R., Almeida, C.T., et al. (2020). Emerging threats linking tropical deforestation and the COVID-19 pandemic. Perspectives in Ecology and Conservation. https:// doi.org/10.1016/j.pecon.2020.09.006

Cabral, R.B., Bradley, D., Mayorga, J., Goodell, W., Friedlander, A.M., Sala, E., Costello, C. and Gaines, S.D. (2020). A global network of marine protected areas for food. Proceedings of the National Academy of Sciences, 117(45): 28134-28139. https://doi.org/10.1073/pnas.2000174117

Carnell, R., Sakpal, P., Pang, I., Mapa, N., and Patterson, W. (2020). Asia's lamentable green response to COVID-19. ING, Economic and Financial Analysis. Available at: https:// think.ing.com/articles/hold-asias-lamentable-green-covid-19response

Claes, J., Conway, M., Hansen, T., Henderson, K., Hopman, D., Katz, J., et al. (2020). Valuing nature conservation: a methodology for quantifying the benefits of protecting the planet's natural capital. McKinsey and Company. Available at: https://www.mckinsey.com/business-functions/sustainability/ our-insights/valuing-nature-conservation\# 
Corlett, R.T., Primack, R.B., Devictor, V., Maas, B., Goswami, V.R., Bates, A.E., et al. (2020). Impacts of the coronavirus pandemic on biodiversity conservation. Biological Conservation, 246, 108571. https://doi.org/10.1016/ j.biocon.2020.108571

Cumming, T., Seidl, A., Emerton, L., Spenceley, A., Golden Kroner, R., Uwineza, Y. and van Zy, H. (2021) Building sustainable finance for resilient protected and conserved areas: lessons from COVID-19. PARKS 27(Special Issue): 149-160 https:/doi.org/10.2305/IUCN.CH.2021.PARKS-27SITC.en

Deutz, A., Heal, G. M., Niu, R., Swanson, E., Townshend, T., Zhu, L., et al. (2020). Financing Nature: Closing the global biodiversity financing gap. The Paulson Institute, The Nature Conservancy, and the Cornell Atkinson Center for Sustainability. Available at: https://www.paulsoninstitute.org/ key-initiatives/financing-nature-report/

Dobson, A.P., Pimm, S.L., Hannah, L., Kaufman, L., Ahumada, J.A., Ando, A.W., et al. (2020). Ecology and economics for pandemic prevention. Science, 369(6502): 379-381. https:// doi.org/10.1126/science.abc3189

Fa, J. E., Watson, J. E. M., Leiper, I., Potapov, P., Evans, T. D., Burgess, N. D., et al. (2020). Importance of Indigenous Peoples' lands for the conservation of Intact Forest Landscapes. Frontiers in Ecology and the Environment. doi:10.1002/fee.2148

Ferreira, M.N., Elliott, W., Golden Kroner, R., Kinnaird, M.F., Prist, P.R., Valdujo, P. and Vale, M.M. (2012). Drivers and causes of zoonotic diseases: an overview, PARKS 27(Special Issue): 31-40 https:/doi.org/10.2305/IUCN.CH.2021.PARKS-27SIMNF.en

Fletcher, R. and Büscher, B. (2020). Conservation basic income: A non-market mechanism to support convivial conservation. Biological Conservation, 244: 108520. https://doi.org/10.1016/ j.biocon.2020.108520

Forest Peoples Programme, International Indigenous Forum on Biodiversity, Indigenous Women's Biodiversity Network, Centres of Distinction on Indigenous and Local Knowledge and Secretariat of the Convention on Biological Diversity (2020). Local Biodiversity Outlooks 2: The contributions of Indigenous peoples and local communities to the implementation of the Strategic Plan for Biodiversity 20112020 and to renewing nature and cultures. A complement to the fifth edition of Global Biodiversity Outlook. Moreton-inMarsh, England: Forest Peoples Programme. Available at: www.localbiodiversityoutlooks.net

Forrest, J. L., Mascia, M. B., Pailler, S., Abidin, S. Z., Araujo, M. D., Krithivasan, R., \& Riveros, J. C. (2015). Tropical Deforestation and Carbon Emissions from Protected Area Downgrading, Downsizing, and Degazettement (PADDD). Conservation Letters, 8(3), 153-161. https://doi.org/10.1111/ conl.12144

Fuchs, R., Brown, C. and Rounsevell, M. (2020). Europe's Green Deal offshores environmental damage to other nations. Nature, 586(7831): 671-673. https://doi.org/10.1038/d41586020-02991-1

Geldmann, J., Barnes, M., Coad, L., Craigie, I.D., Hockings, M. and Burgess, N.D. (2013). Effectiveness of terrestrial protected areas in reducing habitat loss and population declines. Biological Conservation, 161: 230-238. https:// doi.org/10.1016/j.biocon.2013.02.018
Gibb, R., Redding, D.W., Chin, K.Q., Donnelly, C.A., Blackburn, T.M., Newbold, T. and Jones, K.E. (2020). Zoonotic host diversity increases in human-dominated ecosystems. Nature, 584(7821): 398-402. https://doi.org/10.1038/s41586-0202562-8

Gill, D. A., Mascia, M. B., Ahmadia, G. N., Glew, L., Lester, S. E., Barnes, M. et al. (2017). Capacity shortfalls hinder the performance of marine protected areas globally. Nature, 543 (7647), 665-669. https://doi.org/10.1038/nature21708

Golden Kroner, R.E., Qin, S., Cook, C.N., Krithivasan, R., Pack, S.M., Bonilla, O.D., et al. (2019). The uncertain future of protected lands and waters. Science, 364(6443): 881-886. https://doi.org/10.1126/science.aau5525

Goldstein, A., Turner, W. R., Spawn, S. A., Anderson-Teixeira, K. J., Cook-Patton, S., Fargione, J., et al. (2020). Protecting irrecoverable carbon in Earth's ecosystems. Nature Climate Change, 10(4), 287-295. https://doi.org/10.1038/s41558-0200738-8

Hepburn, C., O'Callaghan, B., Stern, N., Stiglitz, J. and Zenghelis, D. (2020). Will COVID-19 fiscal recovery packages accelerate or retard progress on climate change? Oxford Review of Economic Policy, 36(Supplement_1): S359-S381. https:// doi.org/10.1093/oxrep/graa015

Hockings, M., Dudley, N., Elliot, W., Napolitano, M., MacKinnon, K., Pasha, M., et al. (2020). Editorial Essay: Covid-19 and Protected and Conserved Areas. PARKS, 26(1): 7-24.

ICIMOD (2020). COVID-19 impact and policy responses in the Hindu Kush Himalaya. International Centre for Integrated Mountain Development. Available at: https://lib.icimod.org/ record/34863

Kawarazuka, N. and Béné, C. (2011). The potential role of small fish species in improving micronutrient deficiencies in developing countries: Building evidence. Public Health Nutrition, 14(11): 1927-1938. https://doi.org/10.1017/ S1368980011000814

Lindsey, P., Allan, J., Brehony, P., Dickman, A., Robson, A., Begg, C., et al. (2020). Conserving Africa's wildlife and wildlands through the COVID-19 crisis and beyond. Nature Ecology \& Evolution, 4(10): 1300-1310. https://doi.org/10.1038/s41559020-1275-6

Maxwell, S.L., Cazalis, V., Dudley, N., Hoffmann, M., Rodrigues, A.S.L., Stolton, S., et al. (2020). Area-Based Conservation in the 21st Century. Preprints, https://doi.org/10.20944/ preprints202001.0104.v1

McKibbin, W., and Fernando, R. (2020). The global macroeconomic impacts of COVID-19: seven scenarios. Brookings Institute. Available at: https://www.brookings.edu/ research/the-global-macroeconomic-impacts-of-covid-19seven-scenarios/

Naidoo, R., Gerkey, D., Hole, D., Pfaff, A., Ellis, A.M., Golden, C.D., et al. (2019). Evaluating the impacts of protected areas on human well-being across the developing world. Science Advances, 5(4): eaav3006. https://doi.org/10.1126/ sciadv.aav3006

Pack, S.M., Ferreira, M.N., Krithivasan, R., Murrow, J., Bernard, E. and Mascia, M.B. (2016). Protected area downgrading, downsizing, and degazettement (PADDD) in the Amazon. Biological Conservation, 197: 32-39. https://doi.org/10.1016/ j.biocon.2016.02.004

Qin, S., Golden Kroner, R.E., Cook, C., Tesfaw, A.T., Braybrook, R., Rodriguez, C.M., Poelking, C. and Mascia, M.B. (2019). 
Protected area downgrading, downsizing, and degazettement as a threat to iconic protected areas. Conservation Biology, 33(6): 1275-1285. https://doi.org/10.1111/cobi.13365

Schuster, R., Germain, R. R., Bennett, J. R., Reo, N. J., \& Arcese, P. (2019). Vertebrate biodiversity on indigenous-managed lands in Australia, Brazil, and Canada equals that in protected areas. Environmental Science \& Policy, 101, 1-6. https:// doi.org/10.1016/j.envsci.2019.07.002

Shah, V., Shah, A. and Joshi, V. (2018). Predicting the origins of next forest-based emerging infectious disease. Environmental Monitoring and Assessment, 190(6): 337. https:// doi.org/10.1007/s10661-018-6711-6

Siqueira-Gay, J., Soares-Filho, B., Sanchez, L.E., Oviedo, A. and Sonter, L.J. (2020). Proposed legislation to mine Brazil's indigenous lands will threaten Amazon forests and their valuable ecosystem services. One Earth, 3(3): 356-362. https://doi.org/10.1016/j.oneear.2020.08.008

Stolton, S., Dudley, N., Avcıoğlu Çokçalışkan, B., Hunter, D., Ivanić, K.-Z., Kanga, E., et al. (2015) 'Values and benefits of protected areas', in G. L. Worboys, M. Lockwood, A. Kothari, S. Feary and I. Pulsford (eds) Protected Area Governance and Management, pp. 145-168, ANU Press, Canberra, Australia.

Terraube, J. and Fernández-Llamazares, Á. (2020). Strengthening protected areas to halt biodiversity loss and mitigate pandemic risks. Current Opinion in Environmental Sustainability. https://doi.org/10.1016/j.cosust.2020.08.014

Villén-Pérez, S., Moutinho, P., Nóbrega, C.C. and Marco, P.D. (2020). Brazilian Amazon gold: Indigenous land rights under risk. Elementa: Science of the Anthropocene, 8(1): 31. https:// doi.org/10.1525/elementa.427

Waithaka, J., Dudley, N., Álvarez, M., Mora, S.A., Figgis, P., Fitzsimons, J., Gallon, S., Kim, M . et al. (2021). Impacts of COVID-19 on protected and conserved areas: a global overview and regional perspectives. PARKS 27(Special Issue): 41-56 https:/doi.org/10.2305/IUCN.CH.2021.PARKS27-SIJW.en
Waldron, A., Adams, V., Allan, J., Arnell, A., Asner, G., Atkinson, S., et al. (2020). Protecting $30 \%$ of the planet for nature: costs, benefits and economic implications. Working paper analysing the economic implications of the proposed $30 \%$ target for areal protection in the draft post-2020 Global Biodiversity Framework. Available at: https:// www.conservation.cam.ac.uk/files/ waldron_report_30_by_30_publish.pdf

Walker, W. S., Gorelik, S. R., Baccini, A., Aragon-Osejo, J. L., Josse, C., Meyer, C., et al. (2020). The role of forest conversion, degradation, and disturbance in the carbon dynamics of Amazon indigenous territories and protected areas. Proceedings of the National Academy of Sciences, 117 (6), 3015-3025. https://doi.org/10.1073/pnas.1913321117

Wily, A. L. (2011). The tragedy of public lands: The fate of the commons under global commercial pressure. Rome: International Land Coalition.

World Bank Group. (2020). Mobilizing private finance for nature. Available at: http://pubdocs.worldbank.org/ en/916781601304630850/Finance-for-Nature-28-Sep-webversion.pdf

World Economic Forum. (2020). Nature risk rising: Why the crisis engulfing nature matters for business and the economy. New Nature Economy Series. Available at: http:// www3.weforum.org/docs/

WEF_New_Nature_Economy_Report_2020.pdf Wren L. (2020). The economic effects of a pandemic. In R. Baldwin and B. Weder di Mauro (Eds) Economics in the time of COVID -19, pp. 109-112. London, UK: Centre for Economic Policy Research.

Zafra-Calvo, N., Garmendia, E., Pascual, U., Palomo, I., GrossCamp, N., Brockington, D., Cortes-Vazquez, J.-A., Coolsaet, B., \& Burgess, N. D. (2019). Progress toward Equitably Managed Protected Areas in Aichi Target 11: A Global Survey. BioScience, 69(3), 191-197. https://doi.org/10.1093/ biosci/biy143

\footnotetext{
Author affiliations (continued)

7Center for Natural Climate Solutions, Conservation International, 2011 Crystal Drive, Arlington, VA, 22202, USA

${ }^{8}$ West Africa Programme, MAVA Foundation, Mamelles, Rue 21 OKM, villa F46, Dakar, Senegal

${ }_{9}$ Wildland Research Institute, University of Leeds, LS2 9JT, United Kingdom

${ }^{10}$ Observatoire des Forêts d'Afrique Centrale, Secrétariat Exécutif de la COMIFAC, Yaoundé, Cameroon ${ }^{11}$ Territorios Vivos de El Salvador, Calle Las Acacias \#No120 Colonia Vista Hermosa, San Salvador, El Salvador ${ }^{12}$ Conservation Partnerships, Conservation International, Carrera 13 No. 71-41, Bogota DC, Colombia 110231 13United Nations Development Programme Biodiversity Finance Initiative, UN Compound 202-204, Bauddhaloka Mawatha, Colombo 7, Sri Lanka

${ }^{14}$ World Commission on Protected Areas, International Union for the Conservation of Nature, 845 Des Saisons, Gatineau, Québec, J9J 3B9, Canada
} 


\section{RESUMEN}

La pandemia del COVID-19 está teniendo un gran impacto en las políticas y prácticas de conservación a múltiples escalas, incluyendo las áreas protegidas y conservadas (APC). Es necesario comprender las implicaciones para las APC de las recientes medidas, promulgadas o promovidas a raíz del COVID-19. Para llenar este vacío de conocimiento, revisamos los conjuntos de medidas de estímulo económico y otras políticas gubernamentales que fueron impulsadas o implementadas entre enero y octubre de 2020. Identificamos ejemplos positivos de apoyo a las APC en las medidas de recuperación económica (en 17 países) y casos en los que se impulsaron los compromisos contraídos antes de 2020 para ampliar las protecciones ambientales (en 22 países), pero también retrocesos ocasionados en las medidas de protección (64 casos en 22 países). En general, hasta la fecha las medidas y políticas de estímulo económico post COVID han debilitado más que apoyado las protecciones ambientales, incluso en el caso de las APC; los retrocesos pueden tener repercusiones a largo plazo cuando permiten el deterioro de la infraestructura o socavan los derechos de los pueblos indígenas. Sugerimos medidas prioritarias para una recuperación económica verde que incluyen situar a las APC en el centro de dichos esfuerzos para ayudar así a garantizar la prosperidad a largo plazo de las personas y de nuestro planeta.

\section{RÉSUMÉ}

La pandémie COVID-19 engendre des impacts majeurs sur les politiques et les pratiques de conservation à plusieurs échelles, y compris pour les aires protégées et conservées (APC). Il parait nécessaire de comprendre les implications pour les APC des actions récentes, adoptées ou promues suite à l'avènement de la COVID-19. Pour combler ce manque de connaissances, nous avons examiné les plans de relance économique et les autres politiques gouvernementales qui ont été développées ou mises en œuvre entre janvier et octobre 2020. Nous avons identifié des exemples positifs de soutien aux APC dans les programmes de relance économique (dans 17 pays) et des cas où les engagements pris avant 2020 pour renforcer les protections environnementales ont progressé (dans 22 pays), mais aussi des cas de recul de la protection (64 cas dans 22 pays). Dans l'ensemble, les politiques et les plans de relance économique post-COVID à ce jour ont plus entravé que soutenu les protections environnementales, $\mathrm{y}$ compris au sein des APC; les reculs de protection peuvent avoir des conséquences à long terme lorsqu'ils engendrent l'endommagement des infrastructures ou portent atteinte aux droits des populations autochtones. Nous proposons des actions prioritaires pour une reprise économique verte, notamment en plaçant les APC au centre de ces efforts, contribuant ainsi à assurer la prospérité à long terme des populations et de notre planète 